Sukmawani Bela Pertiwi | Changes and Continuities in the Global Health Governance of Coronaviruses

Article

\title{
Changes and Continuities in the Global Health Governance of Coronaviruses
}

\author{
Sukmawani Bela Pertiwi ${ }^{1}$ \\ ${ }^{1}$ Department of International Relations, Bina Nusantara University, Indonesia
}

\section{SUBMISSION TRACK}

$$
\begin{array}{ll}
\text { Received } & : \text { : } 17 \text { September } 2020 \\
\text { Final Revision } & : 31 \text { October } 2020 \\
\text { Available Online } & : 30 \text { November } 2020
\end{array}
$$

\section{KEYWORD}

Actors, Coronaviruses, Global Health Governance, Policies

\section{KATA KUNCI}

Aktor, Kebijakan, Tata Kelola Kesehatan Global, virus Corona

\section{CORRESSPONDENCE}

\section{E-mail : sukmawani.pertiwi@binus.ac.id}

\section{A B S T R A C T}

This paper aims to examine changes and continuities in terms of actors and policies in the global health governance on coronaviruses in order to understand the available tools, the characters and the extent they meet the required responses of a pandemic. In doing so, this paper examines actors and policies in the governance of three occurrences of coronaviruses, i.e. SARS, MERS, and the COVID19. Actors and policies are mapped based on its function in a pandemic: (a) surveillance and knowledge dissemination, (b) material and financial assistance both for emergency and long term purposes, and (c) rule-making behavior. This paper found that the larger scale of the COVID-19 pandemic has led more actors involved in the global governance of COVID-19 than during MERS and SARS. WHO still dominates the surveillance and knowledge dissemination as well as rule making leadership. It also leads in providing material assistance to affected countries. Yet, with the significant impacts to global economy, global financial institutions dominate the provision of financial assistance both for short term and long term commitment. This imbalanced crowd in this last aspect, therefore, causes a changing dominant approach of the GHG on coronaviruses from the previously dominating evidence-based scientific approach to economic approach.

\section{A B S T R A K}

Paper ini bertujuan untuk melihat perubahan dan keberlanjutan dalam hal aktor dan kebijakan tata kelola global terkait virus Corona yang diharapkan dapat membantu memahami sarana-sarana yang ada, karakteristiknya, dan seberapa jauh sarana tersebut memenuhi prasyarat respons terhadap pandemik. Untuk tujuan tersebut, paper ini melihat aktor dan kebijakan pada tiga kejadian virus Corona, yaitu SARS, MERS, and COVID-19. Aktor dan kebijakan dipetakan berdasarkan fungsinya dalam merespon pandemic yaitu: (a) penyebaran informasi dan pengawasan, (b) bantuan finansial dan material baik untuk kondisi darurat maupun jangka panjang, dan (c) perilaku pembuatan aturan. Tulisan ini menemukan bahwa skala besar COVID-19 membuat lebih banyak aktor terlibat dalam tata kelola global selama pandemic COVID-19 dibandingkan dengan saat MERS dan SARS. WHO masih mendominasi dalam penyebaran informasi dan pengawasan serta pembuatan aturan. WHO juga memimpin dalam penyediaan bantuan material kepada negara yang membutuhkan. Meskipun demikian, dengan besarnya dampak terhadap perekonomian global, institusi keuangan global mendominasi dalam penyediaan bantuan finansial baik untuk jangka pendek dan panjang. Fokus pada aspek terakhir ini oleh karenanya, menyebabkan pergeseran dalam hal pendekatan dominan tata kelola global virus Corona, dari yang sebelumnya didominasi oleh pendekatan ilmiah berbasis bukti menjadi pendekatan ekonomi. 


\section{Introduction}

The reported outbreak of a novel coronaviruses (later named as COVID-19) in Wuhan, Hubei Province, China on January 7 , 2020 was soon declared by the WHO as a pandemic on March 11, 2020 as it spread rapidly to 114 countries and affecting 118,000 people around the globe. ${ }^{1}$ As defined by the WHO, pandemic is a phase in the spread of infectious disease that is characterized by "community level outbreak in at least one country in a different WHO region". ${ }^{2}$ In other words, the disease has spread to other parts of the world outside the origin region, or in this case Asia (Western Pacific). In fact, as of April 8, 2020 or three months after the outbreak, the impacts of the pandemic reached 1.3 million people with 74,304 death in 204 countries. ${ }^{3}$ This number far exceeded the SARS outbreak in 2003 which was also caused by coronaviruses (SARS CoV) that affected 26 countries, 8096 people with 774 deaths. ${ }^{4}$ Meanwhile, H1N1 (Swine Flu) Pandemic in 2009 has affected 134,000 people with 816 death in the first three months before it reached its post

1 WHO, (2020a), 2019 Novel Coronavirus (2019$n C o V)$ : Strategic Preparedness and Response Plan, Geneva: WHO; WHO, (2020g, March 11). WHO Director-General's opening remarks at the media briefing on COVID-19 - 11 March 2020. Retrieved April 2020, from WHO: https://www.who.int/dg/speeches/detail/who-directorgeneral-s-opening-remarks-at-the-media-briefing-oncovid-19---11-march-2020

${ }^{2}$ WHO(c). (n.d.). Current WHO phase of pandemic alert for Pandemic (H1NI) 2009. Retrieved April 2020 , from

https://www.who.int/csr/disease/swineflu/phase/en/

${ }^{3}$ WHO, (2020b, April 8), Coronavirus (COVID-19), Retrieved from WHO: https://who.sprinklr.com

${ }^{4}$ J. Mackenzie \& A. Merianos (2013), The legacies of SARS - international preparedness and readiness to respond to future threats in the Western Pacific Region, Western Pacific Surveillance and Response Journal, 4(3), 1-5. pandemic with estimated 18,449 deaths in 214 countries according to the WHO report. ${ }^{5}$

The relatively higher number of cases and death resulting from the COVID-19 have raised serious concerns among all decision makers around the world. Moreover, different from influenza virus, there has been no specific drug and vaccine to respond effectively to the virus. The far rapid movement of people, goods, services, and capital across countries also made the COVID-19 pandemic far more complex than SARS CoV in 2003 as it increases not only the spread of the virus but also the devastating impacts of the pandemic on the global economy. It is even more concerning that the firstly affected countries by the current pandemic are developed countries with China being the first epicenter, the United States as being the most affected, and many European countries dominating the rest of the top ten most affected countries in the first three months.

The implication is that the engine of global economy will be severely affected by the pandemic which will most likely spillover to developing and least developed countries with no less severe impact. This is so because governments in developing and least developed countries have even less financial and technical capacity to detect, report, and treat cases. And currently, with the slowing global economy, capital outflow, aid suspension, lock down and trade restriction from more developed countries, financial burden for these countries becomes overwhelming to deal with the crisis. Another serious implication is that major powers who usually provide global leadership are domestically occupied and thus reducing their ability to offer leadership

\footnotetext{
5 WHO, (2009, July 27), Pandemic (H1N1) 2009 update 59, Retrieved April 2020, from WHO: https:/www.who.int/csr/don/2009 07 27/en/; WHO, (2010, August 6), Pandemic (H1N1) 2009 update 112, Retrieved April 2020, from WHO: https://www.who.int/csr/don/2010_08_06/en/
} 
for "global war" against the pandemic. Leadership is important as theoretically, pandemic is a collective action problem which solution requires cooperation and coordinated action by all actors at all levels. And, under severe enforcement problem, that is when the possibility for states to defect from cooperation is higher, a strong leadership or institution becomes more desirable. $^{6}$

It is at this point that discussion on the global health governance gains its importance as it means that it is currently the only available tool at our disposal at the global level to fight the pandemic amidst the absence of leadership. Yet, global governance is a complex issue which requires understanding in itself. Global governance in general emerges as an approach to understand order, stability, and peace in the anarchic international society amid the absence of global government. The proposed answer to this question is the existence of global governance referring to "the broad range of rules and actors that make up the international regime on an issue". ${ }^{7}$ It includes both "formal and informal, explicit and implicit, regulative and constitutive, state and non-state actors". ${ }^{8}$ The emphasis on issue is important given that there is no single global governance for the world as rules and actors will be different among issues. Therefore, there are global health governance, global economic governance, global environmental governance etc. Even global health governance itself is still broad and dynamic. McInness et.al., for example, categorize global health governance (GHG) into several

${ }^{6}$ S.B. Pertiwi (2020, March 27), Indonesia's Virus Response and What It Tells Us About Global Health Governance, Retrieved April 2020, from The Diplomat: https://thediplomat.com/2020/03/indone sias-virus-response-and-what-it-tells-us-about-globalhealth-governance/

7 I. Hurd, (2014), International Organizations: Politics, Law, Practice, Cambridge: Cambridge University Press.

${ }^{8}$ Ibid. sub-global health governance consisting of GHG on infectious diseases, GHG on noncommunicable diseases, and GHG on distributive issues (such as access to medicine). ${ }^{9}$ Interestingly, each of this GHG involved different actors and are often framed differently by those actors which then shaped different approach to tackle the issue. As McInnes et.al. (2014) observed in their book, the crowd of actors in GHG has led to competing ideas on how to approach the problem with five dominant framing in the GHG are evidence-based medicine, human rights, economics, security and development.

GHG on infectious diseases that is relevant for the discussion here, for example, involve different actors and is framed differently when dealing with pandemic influenza and HIV/AIDs. GHG on pandemic influenza has been mostly framed in the traditional evidence-based medicine (EBM) approach. ${ }^{10}$ This is related to the long history of influenza in human history, the low fatality rate, and the ability of international organization under the leadership of the WHO to control the diseases through its surveillance and vaccine programs. Therefore, global response towards the pandemic influenza has been dominated by scientific medical approach that is well established and relatively unchanged until now. The GHG on pandemic HIV/AIDS, on the other hand, has been framed also and mostly as human rights issue as it affected mostly on specific groups of people such as prostitutes, homosexuals, and many in Africa which contribute to stigmatization to these groups of people. ${ }^{11}$ The issue was also being related to gender, education, and development and thus the GHG on HIV/AIDS involves various actors both from

9 C. McInnes, A. Kamradt-Scott, A., K. Lee, A. Roemer-Mahler, S. Rushton, \& O. Williams. (2014), The Transformation of Global Health Governance, Basingstoke: Palgrave Macmillan.

${ }^{10}$ Ibid.

11 Ibid; T. Weiss \& R. Thakur, (2010), Global Governance and the UN: An Unfinished Journey, Bloomington: Indiana University Press. 
health and non-health sectors and both from IGOs and NGOs. Examples of these actors are the WHO, UNHCR, UNICEF, UNDP, UNODC, UNESCO, ILO, the World Food Program, the UN Population Fund, the World Bank/IMF, Clinton Foundation, Bill and Melinda Gates, Oxfam and individual celebrity initiatives. ${ }^{12}$ The WHO is also no longer the leading actor as the UN established a new coordinating body -the UNAIDS - to specifically coordinate global efforts to deal with the HIV/AIDS. ${ }^{13}$

In regards to the COVID-19 pandemic, the following question is then how is the characteristics of the global health governance on coronaviruses? Who are the main actors and what are their policies? These questions are important not only because few, if none, have developed mapping on the global health governance on coronaviruses which of course has different characteristics from Influenza and HIV/AIDs and thus important for theoretical development, but understanding the characteristics of the GHG on coronaviruses will also help us understand the tools that are available at the global level to fight the pandemic. The COVID-19, however, is not the first occurrence of coronaviruses. There were previously two other occurrences of coronaviruses in the form of SARS in 2002 and MERS in 2012. Understanding the global governance of coronaviruses, therefore, requires understanding on changes and continuities in the emerging global governance in these three occurrences. It is against this background that this study aims to contribute in examining changes and continuities in terms of actors and policies of the global health governance on coronaviruses that is expected to better understand the available tools, their characteristics, and the extent they meet the required response of a pandemic.

\footnotetext{
12 T. Weiss \& R. Thakur, Global Governance and the UN, 299-302.

${ }^{13}$ Ibid., 301.
}

\section{Research Method}

In examining changes and continuities of GHG on coronaviruses, this paper, first of all, identifies actors and policies in the three occurrences of coronaviruses, that is during SARS, MERS, and the COVID-19 with the last mentioned is limited to the first three months of the pandemic that is when this paper is written. As global governance refers to "the exercise of authority across national borders as well as consented norms and rules beyond the nation state, both of them justified with reference to common goods or transnational problems", ${ }^{14}$ this paper bases the mapping of actors on the function of governance that is related to the rule-making and norm-setting during a pandemic. In this regards, Mark W. Zacher and Tania J. Keefe (2008) have identified key strategies commonly used by actors in GHG on infectious diseases that could be used as parameters of governance during a pandemic. ${ }^{15}$ These parameters are essentially in line with the WHO's Strategic Preparedness and Response Plan for the 2019 Novel Coronavirus containing the required preparedness and response plan to fight the pandemic. ${ }^{16}$ Quoted from Zacher and Keefe, these required responses/strategies include:

1) "Promoting surveillance of infectious disease and disseminating knowledge of their impacts"

2) "Providing financial and material assistance for emergency interventions and long-term health improvement program", and

3) "Adopting rules that prescribe and proscribe particular behaviors"

\footnotetext{
14 M. Zürn (2018), A Theory of Global Governance: Authority, Legitimacy, and Contestation, Oxford: Oxford University Press.

15 M. Zacher, \& T. Keefe, (2008), The Politics of Global Health Governance: United by Contagion, New York: Palgrave Macmillan.

16 WHO, (2005), International Health Regulations (2005) (Third Edition), Geneva: WHO.
} 
Based on this parameter, the first governing activity during pandemic involves information gathering on the outbreak of infectious disease, the sources, and the consequence of the outbreak and disseminating this knowledge to all relevant actors. ${ }^{17}$ The first activity, therefore, requires transparency on both the affected countries and people as well as the international organization responsible for this dissemination. The presence of alternative sources of information is also important and will be a sign of greater accountability and good governance. The second governing activity involves the provision of both short term emergency relief to deal with the pandemic in terms of material assistance, such as medical equipment and financial assistance such as emergency fund, as well as long term assistance to establish a better health care system and infrastructure as a preventive measure for the future outbreak. The last activity is rule-making and normsetting that prescribes or constrains behavior. As mentioned in the beginning of this paper, leadership is important to ensure obedience and cooperation from all actors to prevent the spread of the virus. Thus, there must be institution/state which could issue hard law or soft law, rules or norms that could sufficiently help to coordinate actions among actors.

Based on this mapping, this paper then examines changes and continuities in terms of actors and policies across the three occurrences of coronaviruses. Using the above mentioned parameters not only helps in identifying the available tools in the GHG of coronaviruses along with its characteristics but also the extent it meets the required responses or basic governance activities during pandemic.

\section{Result}

The result of this research is presented in Table 1. This table provides summary on the characteristics of the outbreak and the emerging GHG during SARS (2002-2003), MERS (2012-2019), and COVID-19 (2019) from which this study draws analysis on the pattern of changes and continuities of the GHG on coronaviruses and the extent it meets the required response in each occurrence.

\footnotetext{
${ }^{17}$ M. Zacher, \& T. Keefe, The Politics of Global Health Governance, 16.
} 
Sukmawani Bela Pertiwi | Changes and Continuities in the Global Health

Governance of Coronaviruses

Table 1. Actors and Policies in the GHG on Coronaviruses

\begin{tabular}{|c|c|c|c|}
\hline & $\begin{array}{l}\text { SARS-CoV } \\
(2002-2003)\end{array}$ & $\begin{array}{l}\text { MERS-CoV } \\
\text { (2012) }\end{array}$ & $\begin{array}{l}\text { COVID-19 } \\
\text { (2019-Present) }\end{array}$ \\
\hline \multicolumn{4}{|l|}{ Fact Sheet } \\
\hline Origin Country & Guangdong, China & Saudi Arabia & \multirow{2}{*}{$\begin{array}{l}\text { Wuhan, China } \\
1.3 \text { million } \\
(4 / 8 / 2020)\end{array}$} \\
\hline Number of Cases & $8096-8,422$ & $2,494(11 / 2019)$ & \\
\hline Death Rate & $774-916(11 \%)$ & $\begin{array}{ll}858 & (34.4 \%) \\
(11 / 2019) & \end{array}$ & $74,304(4 / 8 / 2020)$ \\
\hline Global Coverage (countries) & $26-29$ & $27(11 / 2019)$ & $204(4 / 8 / 2020)$ \\
\hline \multicolumn{4}{|l|}{ Global Responses } \\
\hline 1a) Surveillance & $\begin{array}{l}\text { WHO (GOARN, } \\
\text { GPHIN, Western } \\
\text { Pacific Office) }\end{array}$ & $\begin{array}{l}\text { WHO (GPHIN), } \\
\text { OIE, FAO }\end{array}$ & WHO \& partners \\
\hline \multirow[t]{2}{*}{ 1b) Disseminating knowledge } & $\begin{array}{l}\text { WHO (GOARN, } \\
\text { GPHIN, Western }\end{array}$ & $\begin{array}{l}\text { WHO (East } \\
\text { Mediterranean }\end{array}$ & \multirow{2}{*}{$\begin{array}{l}\text { WHO, Online } \\
\text { sources by non-state } \\
\text { actors } \\
\text { Worldometer) }\end{array}$} \\
\hline & Pacific Office) & $\begin{array}{l}\text { Regional Office, } \\
\text { GPHIN) , OIE, } \\
\text { FAO, Pro-MED }\end{array}$ & \\
\hline 2a) Providing emergency Financial Assistance & WB & WB & $\begin{array}{l}\text { IMF, WB, G20, } \\
\text { Gates Foundation, } \\
\text { Regional } \\
\text { development banks }\end{array}$ \\
\hline 2b) Providing emergency material assistance & MSF & GOARN & $\begin{array}{l}\text { WHO \& partners, } \\
\text { Gates Foundation, } \\
\text { MSF, Regional } \\
\text { development banks }\end{array}$ \\
\hline 2c) Providing long-term financial assistance & WB & - & WB \\
\hline 2d) Providing long-term material assistance & WB & - & \\
\hline 3) Adopting rules prescribing/proscribing behaviors & WHO, ILO & WHO (Emergency & WHO \\
\hline & & $\begin{array}{l}\text { Committee), OIE, } \\
\text { FAO }\end{array}$ & \\
\hline
\end{tabular}

Sources: Maackenzie \& Merianos, 2013; WHO, 2019a; Park, Thwaites, \& Openshaw, 2020

\section{Discussion}

GHG during The Past Coronaviruses Outbreak

Severely Acute Respiratory Syndrome (SARS) The Severely Acute Respiratory Syndrome (SARS) was the first major case of coronaviruses outbreak in the modern era. It emerged in November 2002 in Foshan City, Guangdong Province, China in the mid of November 2002. The Outbreak occurred in seven separate municipalities with 20 transmission in each chain. ${ }^{18}$ The outbreak began to spread to hospital staffs in January 2003 and peaked in February 2003 with 40

${ }^{18}$ D. Heymann \& G. Rodier, (2004), SARS: A Global Response To An International Threat, Brown Journal of World Affairs, X(2), 186-196. new cases per day totaling 1,512 cases during this local outbreak. ${ }^{19}$ The disease, however, began to spread internationally when one doctor from this area travelled to Hongkong in February and affecting at least 16 people from which this disease spread further to Vietnam, Singapore, and Canada until it reached its peak in May 2003 with 8096-8422 cases and 772-916 deaths in 2629 countries before the WHO declared its triumph in controlling the disease in July $2003 .{ }^{20}$

Observed from the beginning of the crisis, the GHG on SARS demonstrated the

\footnotetext{
19 Ibid.

20 WHO and some academic literatures (see for example Mackenzie \& Merianos) have different numbers on the cases, death, and global coverage. Thus, the table presents the minimum and maximum numbers mentioned from different sources.
} 
leading role of the $\mathrm{WHO}$ in managing the crisis. In terms of surveillance and dissemination of knowledge, the WHO had already cooperated with Canada under the Global Public Health Intelligence Network (GPHIN) since 1997. In essence, GPHIN is an early warning system run by 10 experts conducting observation and analysis based on multilanguage database of news media across countries. ${ }^{21}$ When outbreak emerged in Guangdong in November 2002, GPHIN already noticed this unusual occurrence, yet China was uncooperative by keeping this information both from the international organizations and its own public. ${ }^{22}$ As the WHO surveillance system identified another outbreak in Guangdong on February 10, the WHO disseminated this information through its Global Outbreak Alert and Response Network (GOARN). GOARN is a collaboration of 110 technical and scientific institutions under the leadership of the WHO that was established in 2000 to provide rapid response to an international outbreak. These institutions include, among other, various UN bodies, International NGOs such as Medicine Sans Frontieres (MSF) and MERLIN, the Red Cross, network of laboratories, and scientific institutions from member states. ${ }^{23}$ It is also through this network that the WHO continuously worked

${ }^{21}$ F. Tanguay, (2019, November 12), GHPIN Global Public Health Intelligence Network, Retrieved April 2020, from WHO: https://www.who.int/ docs/defaultsource/eios-gtm-2019-presentations/tang uay-phac--eios-gtm-2019.pdf?sfvrsn=8c758734_2

22 D. Heymann \& G. Rodier, (200̄4), SARS; F.C. Goldizen, (2016), From SARS to Avian Influenza: The Role of International Factors in China's Approach to Infectious Disease Control, Annals of Global Health, 82(1), 180-188; Y. Huang, (2004), The SARS Epidemic and Its Aftermath in China: A Political Perspective, In S. Knobler, A. Mahmoud, S. Lemon, A. Mack, L. Sivitz, \& K. Oberholtzer, Learning from SARS Preparing for the Next Disease Outbreak, Washington, DC: National Academies Press.

23 WHO(e). (n.d.). Global Outbreak Alert and Response Network (GOARN). Retrieved April 2020, from WHO: https:/www.who.int/ihr/alert_and response/outbreak-network/en/ throughout the crisis period to conduct studies on the causes, characteristics and method to deal with the outbreak. It is only one day after this initial information to GOARN partners, which means three months after the first outbreak, that China eventually reported to the $\mathrm{WHO}$, and even so, the local government in Guangdong refused to give access for the WHO to visit the epicenter of the outbreak during its later visit to China. ${ }^{24}$

As countries were unprepared for this short notification of the outbreak, the disease spread quickly to other countries. At this stage, the WHO took over the role as a global rule maker during the crisis, and thus filling the third required response to an outbreak. The WHO issued travel advisories between March to June 2003 in keeping up with the development of the spread of the virus from merely spreading information to international airlines on the symptoms of the affected person to advice to postpone travels to affected areas. ${ }^{25} \mathrm{WHO}$, in this regards, also demonstrated its role as a single authoritative information on the spread of the virus and rule maker in prescribing and proscribing behavior of actors during the crisis. Even after the crisis, the WHO issued "WHO Guidelines For the Global Surveillance of Severe Acute Respiratory Syndrome (SARS)" and "WHO SARS Risk Assessment and Preparedness Framework" both aim to draw lesson from the outbreak and to build better preparedness for any possible reoccurrence. ${ }^{26}$ Interestingly, International Labor Organization (ILO) also

24 F.C. Goldizen, (2016), From SARS to Avian Influenza; D. Heymann \& G. Rodier, (2004), SARS.

${ }^{25}$ WHO, (n.d.), Severe Acute Respiratory Syndrome (SARS) - Travel, Retrieved April 2020, from WHO: https://www.who.int/csr/sars/travel/en/

26 WHO, (2004a, October), WHO guidelines for the global surveillance of severe acute respiratory syndrome (SARS), WHO, Retrieved from https:/www.who.int/csr/resources/publications/WHO

_CDS_CSR_ARO_2004_1.pdf?ua=1;WHO, (2004b), $\bar{W} H O{ }^{-} S A R \bar{S}$ Ris $\bar{k}$ Assessment and Preparedness Framework, WHO. 
issued a guideline responding to the spread of the disease aims specifically for workplace based on the request of ASEAN countries amid fear on the impact of the crisis to job losses and business closure in the region. ${ }^{27}$ This, however, could be seen as complementing and a proof of the adoption of WHO's regulation as the document clearly stated its conformity with the WHO's regulation.

In regards to the financial and material assistance, however, WHO was not the key player. The World Bank Group (WB) which has entered into the GHG in the 1980s demonstrated its contribution by providing financial assistance upon the request of Chinese government. The economic impacts of SARS was widespread, yet China accounted for the $66 \%$ of global cases that it sought financial assistance from the Bank to finance its short term programs in dealing with the outbreak, while at the same time also build stronger health surveillance and disease prevention in the longer term. ${ }^{28}$ This financial assistance was co-financed by Japan, UK, and Canada. In addition to this program, INGOs such as Medicine Sans Frontiere (MSF) also offered material assistance in the form of training and medical equipment for hospitals in China and some other countries affected by the

27 ILO, (2004, March), SARS: Practical and administrative responses to an infectious disease in the workplace, Retrieved April 2020, from ILO: https://www.ilo.org/wcmsp5/groups/public/---ed_pro tect/---protrav/---safework/documents/publication/wc ms_108546.pdf

${ }^{28} \overline{\mathrm{WHO}}$, (2003, December 31), Summary of probable SARS cases with onset of illness from 1 November 2002 to 31 July 2003, Retrieved April 2020, from WHO: https://www.who.int/csr/sars/ country/table2004_04_21/en/; World Bank, (2007, June 29), Implementation Completion and Results Report on Credit/Grant In the Amount of SDR 8.1 Million; US\$ 8 Million to the People's Republic of China. Retrieved April 2020, from World Bank: http://documents.worldbank.org/curated/en/62739146 8214499938/pdf/401860pid0203733600BOX0334059 B.pdf disease. ${ }^{29}$ At this point therefore, it could be concluded that the GHG on SARS in 2003 has been dominated by few actors with the WHO as the leading actor particularly for surveillance and rule-making with predominantly evidence-based scientific approach in dealing with the crisis. Meanwhile the World Bank complemented WHO's role as a traditional provider of financial and material assistance for the affected countries.

\section{Middle East Respiratory Syndrome (MERS)}

The Middle East Respiratory Syndrome (MERS) was a smaller scale coronaviruses outbreak than SARS in 2003, yet it has higher fatality rate and was still found until December 2019 when the COVID 19, a novel coronaviruses emerged in China. The initial indication of this new virus was an outbreak in Zarqa Public Hospital Jordan where one nurse died and eight other staffs suffered from respiratory illness. ${ }^{30}$ GPHIN noticed this unusual occurrence and informed all stakeholders within its network. ${ }^{31}$ Received the same notification, the European Centre for Disease Control and Prevention (ECDC) made its own assessment and asked WHO and US Centre for Disease Control and Prevention (CDC) to follow up the event. ${ }^{32}$ The Jordan Ministry of Health also asked WHO for laboratory investigation on this event, yet based on this testing, all samples are negative for the existing coronaviruses. ${ }^{33}$

\footnotetext{
29 MSF. (2003, May 23). MSF opens program in China to help stop spread of SARS. Retrieved April 2020, from Medicine Sans Frontiere: https://www.msf.org/msf-opens-program-china-helpstop-spread-sars

30 D. R. Lucey, (2014), Still Learning From the Earliest Known MERS Outbreak, Zarqa, Jordan, April 2012, Clinical Infectious Diseases, 59(9), 1234-1236.

${ }^{31}$ M. Dion, P. AbdelMalik \& A. Mawudeku, (2015, September 3), Big Data and the Global Public Health Intelligence Network (GPHIN), Canada Communicable Disease Report, 41(9), 209-214.

${ }^{32}$ D. R. Lucey, (2014), Still Learning From the Earliest Known MERS Outbreak.

${ }^{33}$ Ibid.
} 
In June in the same year, a man admitted to a hospital in Jeddah, Saudi Arabia suffered from similar symptoms. ${ }^{34}$ An Egyptian national working in the hospital, Dr. Ali Mohamed Zaki sent the sample for further investigation to the Ministry of Health. ${ }^{35}$ As no further follow up from the government, Dr. Zaki sent the sample to Dr. Fouchier at Erasmus Medical College in the Netherland which later confirmed the new virus. ${ }^{36}$ Dr. Zaki informed the government and ProMED, a well-established open source internet surveillance response program with thousands of subscribers around the world to fasten the spread of the information. ${ }^{37}$ In a separate case in September, a Qatari man with travel history to Saudi Arabia was admitted to a hospital in the UK with laboratory test showed more than $99 \%$ similarity with the former case in Saudi Arabia. ${ }^{38}$ Given the high probability of the spread of the virus through international travel, the British officials forwarded this information to the WHO which then began its operation and alert to member states. Since the first case in 2012, there have been 837 cases and 291 deaths in 22 countries until mid of $2014 .{ }^{39}$ South Korea became the most affected country outside Saudi Arabia with outbreak occurred in May 2015 resulting in 17,000 quarantined, 186 confirmed cases, and 36 deaths. ${ }^{40}$ The virus

34 J. Youde, (2015), MERS and Global Health Governance, International Journal, 70(1), 119-136.

${ }^{35}$ S. Davies, (2018), Reporting Disease Outbreaks in a World with No Digital Borders. In C. McInnes, K. Lee, \& J. Youde, The Oxford Handbook of Global Health Politics, Oxford: Oxford University Press.

${ }^{36}$ Ibid.

${ }^{37}$ Ibid.

38 WHO, (2012, September 23), Novel coronavirus infection in the United Kingdom. Retrieved April 2020, from WHO: https://www.who.int/csr/don/2012 09 23/en/

39 J. Youde, (2015), MERS and Global Health Governance

${ }^{40}$ K. Kim, H. Yoon \& K. Jung (2017), Resilience in risk communication networks: Following the 2015 MERS response in South Korea, Journal of Contingencies and Crisis Management, 25, 148-159. continued spreading up to 2019 with WHO reported 2,494 cases and 858 deaths until November 2019.41 Even FAO still reported an increase of 33 cases and 46 deaths in February $2020 .^{42}$

The GHG emerging during MERS have similarities and differences with the GHG on SARS. The main similarity is that the WHO was still the leading actor in the GHG on coronaviruses. However, there are more actors joining the efforts in tackling the disease and not to mention the changes in international context during MERS. In surveillance and dissemination of knowledge, for example, GPHIN, has demonstrated another success in early detection of the outbreak in Jordan. The newly revised International Health Regulations (IHR) also gave the WHO a stronger surveillance capacity as it requires member states to report to the WHO on an outbreak of infectious disease within its territory. Member states are also required to develop core capacity to conduct surveillance, provide notification, verification, response, and collaboration. ${ }^{43}$ British and Jordan's decision to report and to involve the WHO on disease outbreak in their territory could be partly explained as a result of growing WHO's power in surveillance mandated by the IHR.

However, during this time, there were also emerging non state actors particularly in the forms of internet surveillance response programs (ISRPs), such as ProMED who could disseminate its surveillance findings on infectious disease to 70,000 subscribers in

\footnotetext{
${ }^{41}$ WHO, (2019a, March 11), Middle East respiratory syndrome coronavirus (MERS-CoV). Retrieved April 2020, from WHO: https://www.who.int/en/newsroom/fact-sheets/detail/ middle-east-respiratorysyndrome-coronavirus-(mers-cov)

42 FAO, (2020, February 19), MERS-CoV Situation Update, Retrieved from FAO: http://www.fao.org/ag/againfo/programmes/en/empres /mers/situation_update.html

43 WHO, (2005), International Health Regulations (2005) (Third Edition), Geneva: WHO.
} 
185 countries. ${ }^{44}$ This was proven in the case of MERS in Saudi Arabia when Dr. Zaki forwarded the information on the new virus to ProMED which then contributed to earlier detection on cases of MERS around the world. However, while the IHR also gives access for non-state actors to report directly to the WHO of a disease outbreak, there was impression that this non-state type of report have been in some cases overlooked both by the WHO and the government in individual country which perhaps to some extent signaled the desire of the $\mathrm{WHO}$ to maintain its central place in the coordination of surveillance activities. ${ }^{45}$

In the rule making response, WHO also demonstrated, and ideally demonstrate, a strong if not stronger role as an international rule-maker as it was equipped with the newly revised IHR which provides guidelines and regulations that states have to follow in the global health governance on infectious disease. Under the IHR, the WHO also convened the IHR Emergency Committee who are tasked to offer technical recommendation to the WHO. ${ }^{46}$ The EC conducted regular meetings from 2013 to 2015 which became the basis for the WHO to determine the status level of MERS and to issue advices to various stakeholders at all level. ${ }^{47}$ The meeting of the EC also became an additional surveillance and knowledge dissemination tools of the WHO as it gathered experts and actors from the affected countries to formulate the policies.

Perhaps the stark changes in the way the WHO lead the rule making, and also surveillance activities, is that it adopted a

${ }^{44}$ Davies, (2018), Reporting Disease Outbreaks in a World.

45 Ibid.

46 WHO, (2013, July 9), Middle East respiratory syndrome coronavirus (MERS-CoV), Retrieved April 2020, from WHO: https://www.who.int/ihr/procedures/statements_20130 709/en/

47 WHO(f), (n.d.), IHR Emergency Committee concerning Middle East respiratory syndrome coronavirus, Retrieved April 2020, from WHO: https://www.who.int/ihr/ihr_ec_2013/en/ more collective leadership with the Food and Agriculture Organization (FAO) and the World Organization for Animal Health (OIE) ${ }^{48}$ As MERS is a zoonotic disease comes from animal, collaborating with FAO and OIE is important in understanding the characteristics and transmission of the disease and to develop a well-informed policy and guidelines on this disease. ${ }^{49}$ The three organizations regularly held technical meetings, and in 2009, issued A Tripartite Guide to Addressing Zoonotic Diseases in Countries which updated the previous guidelines on similar matter. ${ }^{50}$ One persistent problem in WHO's rule-making behavior even after the revised IHR was its inability to force compliance and transparency among member states, or at least from the origin country of the disease. It took three months for China to eventually report to the WHO on the outbreak of SARS. Saudi's dismissal of Dr. Zaki's report and its lack of transparency on its handling of the disease also delayed the response to the disease and could set negative precedence for any individuals/non state actors reporting cases in particular state as their action might have serious risk for their personal security. ${ }^{51}$

Lastly, in terms of financial and material assistance, there were only few actors involved as MERS had smaller scale than SARS and $80 \%$ of its cases were from Saudi Arabia. Among the existing actors, GOARN was perhaps among the few that contributed to provide material assistance

\footnotetext{
${ }^{48}$ WHO, (2019b, March 11), Middle East respiratory syndrome coronavirus (MERS-CoV): Key facts, Retrieved April 2020, from WHO: https:/www.who.int/en/news-room/fact-sheets/detail/ middle-east-respiratory-syndrome-coronavirus-(merscov)

${ }^{49}$ FAO-OIE-WHO MERS Technical Working Group. (2018). MERS: Progress on the global response, remaining challenges and the way forward. Antiviral Research, 159, 35-44.

50 Ibid.

51 Davies, (2018), Reporting Disease Outbreaks in a World.
} 
through its deployment to Tunisia in $2013 .{ }^{52}$ The World Bank also has Pandemic Emergency Financing Facility which include MERS, yet there is information on the state, if any, who take advantage of this facility. ${ }^{53}$ Thus, it can be said at this point that similar with SARS, GHG on coronaviruses during MERS was still dominated by the WHO with its evidence-based scientific approach. Few changes was unavoidable to response to the changing international context in those years.

\section{GHG during The COVID-19 Pandemic}

As mentioned in the beginning of this paper, the COVID-19 pandemic has far more cases, deaths, and global coverage than SARS and MERS. While it has lower fatality rate so far compared to MERS, COVID-19 is highly transmissible and thus it gains fertile ground to spread widely in the current environment which has far more intense transactions and mobility of goods, people, and services across countries. This is not to mention the advanced information technology which in the one hand help to promote transparency, but in the other hand created more panic and noise among people around the world. The emerging GHG during the COVID-19 pandemic, therefore, involves more actors as it is impossible for the $\mathrm{WHO}$ with the current resources to handle the pandemic alone given the health, social, and economic impact of the pandemic.

The beginning of the pandemic could be traced back to December 31, 2009 when the WHO's office in China received notification on an outbreak of pneumonia in Wuhan, Hubei Province. ${ }^{54}$ Based on the

52 J.S. Mackenzie et.al., (2014), The Global Outbreak Alert and Response Network, Global Public Health, 9(9), 1023-1039.

53 World Bank, (2017, May 9), Pandemic Emergency Financing Facility: Frequently Asked Questions, Retrieved April 2020, from The World Bank: https://www.worldbank.org/en/topic/pande $\mathrm{mics} /$ brief/pandemic-emergency-facility-frequentlyasked-questions

54 WHO, (2020d, January 20). Novel Coronavirus (2019-nCoV) SITUATION REPORT - 1, Retrieved April 2020, from laboratory investigation on January 7 , this outbreak was caused by a novel coronavirus more likely emerged from a local seafood market. China shared this genome sequence on January 12 which could help detect similar cases and which apparently soon be found in Thailand the next day (January 13), Japan on January 15, and Korea on January $20 .{ }^{55}$ By the end of January, this number increased to 9,826 cases of which 9,720 are from China and 106 are from outside China. This composition changed dramatically however, as on April 8, China accounted for only $6 \%$ of the total global cases $(83,157$ out of $1,353,361)$, meaning that this disease has widely spread around the world which collectively share more than $90 \%$ of the cases with no sign of leveling out yet during the time of this writing. ${ }^{56}$

Given this unprecedented scale of the pandemic, there are quite significant changes in the existing GHG compared to the past coronaviruses. In terms of surveillance and knowledge dissemination, WHO has strengthened its surveillance system with GPHIN is currently collaborating with ProMed and HealthMap under the Epidemic Intelligence from Open Source (EIOS) initiative. EIOS has identified the outbreak of pneumonia in Wuhan on December 31, and perhaps it is also from this notification that the WHO office received information on the outbreak on the same date. ${ }^{57}$ On January 2 , WHO activated its incident management system as a standardized approach adopted by the WHO in responding to emergency run by incident management team in six

https:/www.who.int/docs/default-source/coronavi ruse/situation-reports/20200121-sitrep-1-2019ncov.pdf?sfvrsn=20a99c10_4

${ }^{55}$ Ibid.

56 WHO, (2020c, April 8), Coronavirus disease 2019 (COVID-19) Situation Report - 79, Retrieved April 2020, from WHO: https://www.who.int/docs/defaultsource/coronavi ruse/situation-reports/20200408sitrep-79-covid-19.pdf?sfvrsn=4796b143_6

$57 \mathrm{WHO}(\mathrm{d})$, (n.d.), Epidemic Intelligence from Open Sources (EIOS), Retrieved April 2020, from WHO: https:/www.who.int/eios 
main areas i.e. leadership, partner coordination, information and planning, health operations and technical expertise, operations support and logistics, and finance and administration. ${ }^{58} \mathrm{WHO}$ also activated its R\&D blueprint to begin its R\&D activities on the possible vaccine and drug for the virus. ${ }^{59}$ In disseminating the knowledge, the WHO uses a new platform named WHO Information Network for Epidemic (EPIWIN). ${ }^{60}$ In essence, the WHO is now better equipped with the information system and collaboration with various actors in conducting surveillance and knowledge dissemination. The presence of other nonstate actors both global and local, such as Worldometer and KawalCOVID19 in Indonesia, in reporting cases also strengthen transparency and accountability which are important in time of crisis.

In the area of rule-making, the WHO is still the leading actor in responding to the crisis. When the disease emerged, the WHO activated Emergency Committee under the IHR as it did during MERS. It was this EC who then determined the changing status of the disease as to whether it is categorized as public health emergency of international concern and whether there have been sufficient evidences to raise the level of the outbreak to pandemic level. The EC also offers recommendation on WHO's public advice for general public and technical guidance for more specific groups at the

58 WHO, (2017), Emergency Response Framework (Second Edition), Geneva; WHO, (2020e, January 25), Novel Coronavirus (2019-nCoV) SITUATION REPORT - 5, Retrieved April 2020, from WHO: https://www.who.int/docs/default-

source/coronaviruse/situation-reports/20200125sitrep-5-2019-ncov.pdf?sfvrsn=429b143d_8

$59 \mathrm{WHO}(\mathrm{h})$, (n.d.), R\&D Blueprint, Retrieved April 2020, from WHO: https://www.who.int/ blueprint/about/en/

60 WHO, (2020f, January 31), Novel Coronavirus(2019-nCoV) Situation Report - 11, Retrieved April 2020, from WHO: https://www.who.int/docs/default-source/coronavi ruse/situation-reports/20200131-sitrep-11ncov.pdf? sfvrsn=de $7 \mathrm{c} 0 \mathrm{f} 7 \_4$ national and local levels. ${ }^{61}$ One of the most notable advice which could be said a new international norm during this pandemic is WHO's norm of social distancing. It is perhaps one important aspect which are often underestimated as many observers often criticized international organizations, including the WHO, for its inability in offering material assistance to affected countries and its ineffectiveness in forcing member states' compliance. While the critics is justified as, for example, the WHO does not have capacity to force member states to close their borders simultaneously, this critics disregards the limited resources and competencies transferred by member states to the organization. In addition, their emphasis on material role of an international organization also underestimate their normative role in setting the norms to be followed during crisis. Norms could not force compliance, but it helps setting guidelines for the society to prevent further spread of the virus particularly in a state whose government does not act sufficiently to contain the virus.

Lastly, in the area of providing material and financial assistance, there is a significant change as the WHO demonstrates a strengthened presence in this area, but at the same time there are far more numbers of actors joining the efforts. In the previous coronaviruses occurrence, the WHO offered limited material assistance as the preceding two occurrence were smaller and need no international intervention. During this pandemic, however, the WHO not only works closely with GOARN in providing technical assistance in affected countries, but also other key partners, such as Global Health Cluster, Standby Partnerships, and Emergency Medical Teams (WHO(g),

${ }^{61} \mathrm{WHO}(\mathrm{a})$, (n.d.), Coronavirus disease (COVID-19) Pandemic, Retrieved April 2020, from WHO: https:/www.who.int/emergencies/diseases/ novelcoronavirus-2019 
n.d.) ${ }^{62}$ It also clearly stated that it requires US\$675 millions for meeting the Strategic Preparedness and Response Plan which includes material assistance in the form of medical equipment, knowledge dissemination, and technical assistance in the form of clinical management capacity building. ${ }^{63}$ In addition to releasing its Contingency Fund for Emergency, the WHO also collected donation in the form of COVID-19 Solidarity Response Fund to meet this required amount. Interestingly, this donation shows the significant contribution from non-state actors such as Gates Foundation, Federation Internationale de Football Association (FIFA), Holy See, King Baudouin Foundation, and Vital Strategies which also signifies their positive support in strengthening the role of the WHO in tackling the pandemic. ${ }^{64}$

WHO's assistance, however, focuses on material assistance, and thus as the pandemic began to affect global economy, key international financial institutions also offer their contribution in filling the gap of providing financial assistance to affected countries. The World Bank, for example, offers long term and fast-track financial support up to $\$ 160$ millions and $\$ 14$ billions respectively. ${ }^{65}$ While the first was dedicated for the public sector, the later include $\$ 8$ billion funding from the International Finance Corporation (IFC) to help private companies. ${ }^{66}$ Development banks at the

${ }^{62} \mathrm{WHO}($ g), (n.d.), Partners and Networks. Retrieved April 2020, from WHO: https://www.who.int/emergencies/partners

${ }^{63}$ WHO (b), (n.d.). COVID-19 Response Fund, Retrieved April 2020, from WHO: https://www.who.int/emergencies/diseases/novelcoronavirus-2019/donors-and-partners/funding 64 Ibid.

${ }^{65}$ World Bank, (2020a, February 11), How the World Bank Group is helping countries with COVID-19 (coronavirus), Retrieved April 2020, from The World Bank: https://www.worldbank.org/en/ news/factsheet/2020/02/11/how-the-world-bankgroup-is-helping-countries-with-covid-19-coronavirus ${ }^{66}$ WHO, (2020b, April 8), Coronavirus (COVID-19), Retrieved from WHO: https://who.sprinklr.com regional level, such as ADB and AIIB in Asia also offer their assistance. The ADB has technical assistance grants for the public sector as much as \$2 million for China and the Mekong subregion and another \$2 million for developing member countries in general. ${ }^{67}$ For the private sector, the ADB offers \$18.6 million short-term loan mechanism. Meanwhile, the newly established AIIB is currently proposing a total of $\$ 5$ billion Crisis Recovery Facility both for private and public sectors of the member countries. ${ }^{68}$

The IMF as the leading institution tasked with maintaining global economic stability, also offers five main mechanism to help countries suffering from negative balance of payment, capital outflow, companies' bankruptcy and unemployment as a result of the pandemic. These mechanism include emergency financing in the form of Rapid Credit Facility (RCF) for the poorest countries and Rapid Financing Instrument (RFI) for all member countries, debt relief grant for the poorest countries, financing under the existing program, new financing arrangement, and capacity development. ${ }^{69}$ As of April 9, however, there are more than 90 countries applying to the estimated $\$ 50$ billions available emergency financing in the IMF at the same time which means more partnership needed to meet this demand. ${ }^{70}$ Last but not least, the G20 as the

67 ADB, (n.d.), COVID-19, Retrieved April 2020, from ADB: https://www.adb.org/what-wedo/covid19-coronavirus

${ }^{68}$ AIIB, (2020, April 3), AIIB Looks to Launch USD5 Billion COVID-19 Crisis Recovery Facility, Retrieved April 2020, from AIIB: https://www.aiib.org/en/newsevents/news/2020/AIIB -Looks-to-Launch-USD5Billion-COVID-19-Crisis-Recovery-Facility.html 69 IMF, (2020a, March 2), How the IMF Can Help Countries Address Economic Effects of Coronavirus An Infographic, Retrieved April 2020, from International Monetary Fund: https://www.imf.org/en/About/Factsheets/Sheets/2020 /02/28/how-the-imf-can-help-countries-address-theeconomic-impact-of-coronavirus/coronavirusinfographic

70 IMF, (2020b, April 9), The IMF's Response to COVID-19, Retrieved April 2020, from International 
grouping of the 20 biggest economy in the world, also announced their commitment to contribute to fill the financing gap in the WHO, and with close cooperation with the IMF and the World Bank Group, committed to contribute $\$ 5$ trillion rescue package to deal with the economic impact of the pandemic..$^{71}$ The pledge by the G20 gives not only significant financial resources to fight against the pandemic but also a symbol of major powers' support for international institutions. G20's successful record in dealing with the 2009 global financial crisis has also increased expectation for this grouping to repeat the same success during this pandemic. The overwhelming number of actors in providing financial assistance, however, has shifted the dominant approach in framing the crisis from the evidence-based scientific approach to economic approach.

\section{Conclusion}

This paper begin with the goal of examining changes and continuities in terms of actors and policies of the global health governance on coronaviruses that is expected to better understand the available tools, their characteristics, and the extent they meet the required response of a pandemic. Based on the elaboration of this paper, there are several conclusion that could be drawn from this study. First, GHG on coronaviruses is different from GHG on other infectious diseases and thus deserve a separate study. Second, GHG on coronaviruses is very dynamic as there are continuity and changes in terms of actors and the dominant approach from SARS, MERS, to COVID-19. Third, in each occurrence, the contribution of actors

\footnotetext{
Monetary $\quad$ Fund: https://www.imf.org/ en/About/FAQ/imf-response-to-covid-19

71 G20 Information Centre, (2020, March 26), Extraordinary G20 Leaders' Summit: Statement on COVID-19, Retrieved April 2020, from G20 Information Centre University of Toronto: http://www.g20.utoronto.ca/2020/2020-g20statement-0326.html
}

and policies to the required responses during pandemic could be seen in three aspects: 1) surveillance and knowledge dissemination, 2) financial and material assistance both for emergency and long term purposes, and 3) rule making behavior. Based on these parameter, this research shows that in terms of surveillance, knowledge dissemination, and rule-making behavior, WHO has consistently demonstrated its leading role from SARS, MERS, to the COVID-19. However, while WHO's role in surveillance has been strengthened by the participation of non-state actors and the advanced of information technology, WHO's role as a rule maker do not become stronger even though it has been equipped with the IHR. WHO's rule making behavior remains limited to producing soft law/norms in responding the crisis. In terms of financial and material assistance, WHO has demonstrated stronger presence in providing material assistance during the COVID-19 compared to the past coronaviruses outbreaks. Yet, provision of financial assistance is still dominated by financial institutions. Particularly during the COVID19 pandemic, there are overwhelming number of actors in this area which then shifted the dominant approach in framing the coronaviruses outbreak from previously dominated by scientific approach to more economic dominated approach. While mitigating the economic impact of the pandemic is important, there must be equal tools in the other aspects because economic measure will be less effective if the pandemic itself is still unresolved. 
Sukmawani Bela Pertiwi | Changes and Continuities in the Global Health

Governance of Coronaviruses

\section{REFERENCES}

ADB. (n.d.). COVID-19. Retrieved April 2020, from ADB: https://www.adb.org/what-wedo/covid19-coronavirus

AIIB. (2020, April 3). AIIB Looks to Launch USD5 Billion COVID-19 Crisis Recovery Facility. Retrieved April 2020, from AIIB: https://www.aiib.org/en/newsevents/news/2020/AIIB-Looks-to-Launch-USD5-Billion-COVID-19-CrisisRecovery-Facility.html

Davies, S. (2018). Reporting Disease Outbreaks in a World with No Digital Borders. In C. McInnes, K. Lee, \& J. Youde, The Oxford Handbook of Global Health Politics. Oxford: Oxford University Press.

Dion, M., AbdelMalik, P., \& Mawudeku, A. (2015, September 3). Big Data and the Global Public Health Intelligence Network (GPHIN). Canada Communicable Disease Report, 41(9), 209-214.

FAO. (2020, February 19). MERS-CoV Situation Update. Retrieved from FAO: http://www.fao.org/ag/againfo/programmes/en/empres/mers/situation_update.html

FAO-OIE-WHO MERS Technical Working Group. (2018). MERS: Progress on the global response, remaining challenges and the way forward. Antiviral Research, 159, 35-44.

G20 Information Centre. (2020, March 26). Extraordinary G20 Leaders' Summit: Statement on COVID-19. Retrieved April 2020, from G20 Information Centre University of Toronto: http://www.g20.utoronto.ca/2020/2020-g20-statement-0326.html

Goldizen, F. C. (2016). From SARS to Avian Influenza: The Role of International Factors in China's Approach to Infectious Disease Control. Annals of Global Health, 82(1), 180188.

Heymann, D., \& Rodier, G. (2004). SARS: A Global Response To An International Threat. Brown Journal of World Affairs, X(2), 186-196.

Huang, Y. (2004). The SARS Epidemic and Its Aftermath in China: A Political Perspective. In S. Knobler, A. Mahmoud, S. Lemon, A. Mack, L. Sivitz, \& K. Oberholtzer, Learning from SARS Preparing for the Next Disease Outbreak. Washington, DC: National Academies Press.

Hurd, I. (2014). International Organizations: Politics, Law, Practice. Cambridge: Cambridge University Press.

ILO. (2004, March). SARS: Practical and administrative responses to an infectious disease in the workplace. Retrieved April 2020, from ILO: https://www.ilo.org/wcmsp5/groups/public/---ed_protect/---protrav/--safework/documents/publication/wcms_108546.pdf

IMF. (2020a, March 2). How the IMF Can Help Countries Address Economic Effects of Coronavirus - An Infographic. Retrieved April 2020, from International Monetary Fund: https://www.imf.org/en/About/Factsheets/Sheets/2020/02/28/how-the-imf-canhelp-countries-address-the-economic-impact-of-coronavirus/coronavirus-infographic

IMF. (2020b, April 9). The IMF's Response to COVID-19. Retrieved April 2020, from International Monetary Fund: https://www.imf.org/en/About/FAQ/imf-response-tocovid-19

Kim, K., Yoon, H., \& Jung, K. (2017). Resilience in risk communication networks: Following the 2015 MERS response in South Korea. Journal of Contingencies and Crisis Management, 25, 148-159. 
Sukmawani Bela Pertiwi | Changes and Continuities in the Global Health

Governance of Coronaviruses

Lucey, D. R. (2014). Still Learning From the Earliest Known MERS Outbreak, Zarqa, Jordan, April 2012. Clinical Infectious Diseases, 59(9), 1234-1236.

Mackenzie et.al., J. S. (2014). The Global Outbreak Alert and Response Network. Global Public Health, 9(9), 1023-1039.

Mackenzie, J., \& Merianos, A. (2013). The legacies of SARS - international preparedness and readiness to respond to future threats in the Western Pacifi c Region. Western Pacific Surveillance and Response Journal, 4(3), 1-5.

McInnes, C., Kamradt-Scott, A., Lee, K., Roemer-Mahler, A., Rushton, S., \& Williams, O. (2014). The Transformation of Global Health Governance. Basingstoke: Palgrave Macmillan.

MSF. (2003, May 23). MSF opens program in China to help stop spread of SARS. Retrieved April 2020, from Medicine Sans Frontiere: https://www.msf.org/msf-opens-programchina-help-stop-spread-sars

Park, M., Thwaites, R., \& Openshaw, P. (2020). COVID-19: Lessons from SARS and MERS. European Journal of Immunology, 50, 308-316.

Pertiwi, S. B. (2020, March 27). Indonesia's Virus Response and What It Tells Us About Global Health Governance. Retrieved April 2020, from The Diplomat: https://thediplomat.com/2020/03/indonesias-virus-response-and-what-it-tells-usabout-global-health-governance/

Tanguay, F. (2019, November 12). GHPIN Global Public Health Intelligence Network. Retrieved April 2020, from WHO: https://www.who.int/docs/default-source/eios-gtm2019-presentations/tanguay-phac---eios-gtm-2019.pdf?sfvrsn=8c758734_2

Weiss, T., \& Thakur, R. (2010). Global Governance and the UN: An Unfinished Journey. Bloomington: Indiana University Press.

WHO (b). (n.d.). COVID-19 Response Fund. Retrieved April 2020, from WHO: https://www.who.int/emergencies/diseases/novel-coronavirus-2019/donors-andpartners/funding

WHO. (2003, December 31). Summary of probable SARS cases with onset of illness from 1 November 2002 to 31 July 2003. Retrieved April 2020, from WHO: https://www.who.int/csr/sars/country/table2004_04_21/en/

WHO. (2004a, October). WHO guidelines for the global surveillance of severe acute respiratory syndrome (SARS). WHO. Retrieved from https://www.who.int/csr/resources/publications/WHO_CDS_CSR_ARO_2004_1.pdf? ua $=1$

WHO. (2004b). WHO SARS Risk Assessment and Preparedness Framework. WHO.

WHO. (2005). International Health Regulations (2005) (Third Edition). Geneva: WHO.

WHO. (2009, July 27). Pandemic (H1N1) 2009 - update 59. Retrieved April 2020, from WHO: https://www.who.int/csr/don/2009_07_27/en/

WHO. (2010, August 6). Pandemic (H1N1) 2009 - update 112. Retrieved April 2020, from WHO: https://www.who.int/csr/don/2010_08_06/en/

WHO. (2012, September 23). Novel coronavirus infection in the United Kingdom. Retrieved April 2020, from WHO: https://www.who.int/csr/don/2012 09 23/en/

WHO. (2013, July 9). Middle East respiratory syndrome coronavirus (MERS-CoV). Retrieved April 2020, from https://www.who.int/ihr/procedures/statements_20130709/en/

WHO. (2017). Emergency Response Framework (Second Edition). Geneva.

WHO. (2019a, March 11). Middle East respiratory syndrome coronavirus (MERS-CoV). Retrieved April 2020, from WHO: https://www.who.int/en/news-room/factsheets/detail/middle-east-respiratory-syndrome-coronavirus-(mers-cov) 
Sukmawani Bela Pertiwi | Changes and Continuities in the Global Health

Governance of Coronaviruses

WHO. (2019b, March 11). Middle East respiratory syndrome coronavirus (MERS-CoV): Key facts. Retrieved April 2020, from WHO: https://www.who.int/en/news-room/factsheets/detail/middle-east-respiratory-syndrome-coronavirus-(mers-cov)

WHO. (2020a). 2019 Novel Coronavirus (2019-nCoV): Strategic Preparedness and Response Plan. Geneva: WHO.

WHO. (2020b, April 8). Coronavirus (COVID-19). Retrieved from WHO: https://who.sprinklr.com

WHO. (2020c, April 8). Coronavirus disease 2019 (COVID-19) Situation Report - 79. Retrieved April 2020, from WHO: https://www.who.int/docs/defaultsource/coronaviruse/situation-reports/20200408-sitrep-79-covid-

19.pdf?sfvrsn=4796b143_6

WHO. (2020d, January 20). Novel Coronavirus (2019-nCoV) SITUATION REPORT - 1. Retrieved April 2020, from WHO: https://www.who.int/docs/defaultsource/coronaviruse/situation-reports/20200121-sitrep-1-2019-

ncov.pdf?sfvrsn=20a99c10_4

WHO. (2020e, January 25). Novel Coronavirus (2019-nCoV) SITUATION REPORT - 5. Retrieved April 2020, from WHO: https://www.who.int/docs/defaultsource/coronaviruse/situation-reports/20200125-sitrep-5-2019ncov.pdf?sfvrsn $=429 \mathrm{~b} 143 \mathrm{~d} \_8$

WHO. (2020f, January 31). Novel Coronavirus(2019-nCoV) Situation Report - 11. Retrieved April 2020, from WHO: https://www.who.int/docs/defaultsource/coronaviruse/situation-reports/20200131-sitrep-11-ncov.pdf?sfvrsn=de7c0f7_4

WHO. (2020g, March 11). WHO Director-General's opening remarks at the media briefing on COVID-19 - 11 March 2020. Retrieved April 2020, from WHO: https://www.who.int/dg/speeches/detail/who-director-general-s-opening-remarks-atthe-media-briefing-on-covid-19---11-march-2020

WHO Regional Office for the Eastern Mediteranian. (2019, November). MERS Situation Update. Retrieved April 2020, from WHO: http://applications.emro.who.int/docs/EMRPUB-CSR-241-2019EN.pdf?ua $=1 \& u a=1 \& u a=1$

WHO. (n.d.). Severe Acute Respiratory Syndrome (SARS) - Travel. Retrieved April 2020, from WHO: https://www.who.int/csr/sars/travel/en/

WHO(a). (n.d.). Coronavirus disease (COVID-19) Pandemic. Retrieved April 2020, from WHO: https://www.who.int/emergencies/diseases/novel-coronavirus-2019

WHO(c). (n.d.). Current WHO phase of pandemic alert for Pandemic (H1N1) 2009. Retrieved April 2020, from https://www.who.int/csr/disease/swineflu/phase/en/

WHO(d). (n.d.). Epidemic Intelligence from Open Sources (EIOS). Retrieved April 2020, from WHO: https://www.who.int/eios

WHO(e). (n.d.). Global Outbreak Alert and Response Network (GOARN). Retrieved April 2020, from WHO: https://www.who.int/ihr/alert_and_response/outbreak-network/en/

WHO(f). (n.d.). IHR Emergency Committee concerning Middle East respiratory syndrome coronavirus. Retrieved April 2020, from WHO: https://www.who.int/ihr/ihr_ec 2013/en/

WHO(g). (n.d.). Partners and Networks. Retrieved April 2020, from WHO: https://www.who.int/emergencies/partners

WHO(h). (n.d.). R\&D Blueprint. Retrieved April 2020, from WHO: https://www.who.int/blueprint/about/en/ 
Sukmawani Bela Pertiwi | Changes and Continuities in the Global Health

Governance of Coronaviruses

WHO, FAO, OIE. (2019). Taking a Multisectoral, One Health Approach: A Tripartite Guide to Addressing Zoonotic Diseases in Countries. WHO, FAO, OIE.

World Bank. (2007, June 29). Implementation Completion and Results Report on Credit/Grant In the Amount of SDR 8.1 Million; US\$ 8 Million to the People's Republic of China. Retrieved April 2020, from World Bank: http://documents.worldbank.org/curated/en/627391468214499938/pdf/401860pid020 3733600BOX0334059B.pdf

World Bank. (2017, May 9). Pandemic Emergency Financing Facility: Frequently Asked Questions. Retrieved April 2020, from The World Bank: https://www.worldbank.org/en/topic/pandemics/brief/pandemic-emergency-facilityfrequently-asked-questions

World Bank. (2020a, February 11). How the World Bank Group is helping countries with COVID-19 (coronavirus). Retrieved April 2020, from The World Bank: https:/www.worldbank.org/en/news/factsheet/2020/02/11/how-the-world-bankgroup-is-helping-countries-with-covid-19-coronavirus

World Bank. (2020b, March 17). World Bank Group Increases COVID-19 Response to \$14 Billion To Help Sustain Economies, Protect Jobs. Retrieved April 2020, from The World Bank: https://www.worldbank.org/en/news/press-release/2020/03/17/worldbank-group-increases-covid-19-response-to-14-billion-to-help-sustain-economiesprotect-jobs

Youde, J. (2015). MERS and Global Health Governance. International Journal, 70(1), 119136.

Zürn, M. (2018). A Theory of Global Governance: Authority, Legitimacy, and Contestation. Oxford: Oxford University Press.

Zacher, M., \& Keefe, T. (2008). The Politics of Global Health Governance: United by Contagion. New York: Palgrave Macmillan. 